\title{
Paris Conference 1946 - organizational principles of the Peace Conference Štefan ŠUTAJ
}

\author{
Katedra histórie Filozofickej fakulty Univerzity P. J. Šafárika v Košiciach \\ Department of History, Faculty of Arts, Pavol Jozef Šafárik University, Košice \\ Petzvalova 4, 04011 Košice, Slovakia \\ stefan.sutaj@upjs.sk
}

The Paris Peace Conference held in 1946 affected significantly the European and Central European politics. It was a place of confrontation, but also of finishing the basic lines of postwar political orientation and of international political positions of the involved and interested countries. The Paris Conference of 1946 became a glacis of the fight for future shape of the European politics and their values. The then existing line between the winning and defeated countries faded away there. The allegiance to power-political blocs became dominant.

The peace treaties resulted from complicated negotiations that had started when it was evident that Germany and its allies would be defeated. After the foreign ministers of the United States of America, the Union of Soviet Socialist Republics and the United Kingdom at the Moscow Conference held in 1943 had festively declared that the unified progress of warfare would be preserved even after its termination, in organization of peace and safety, the representatives of the three Great Powers decided at the Yalta Conference in February 1945 to take common measures to solve political and economic problems of the nations liberated from the Nazi dominance and of the nations of former Axis satellites. Similarly to the preceding periods, the future of the world was to be decided at a peace conference after World War II as well.

Pragmatic politicians certainly saw very clearly that the world diplomacies were facing negotiations that could determine the positions of states (nations) for a long period. Not to make use of them could constitute a deficit not only for the positions of the representations at that time but also for the fate of their states in the future.

At the Potsdam Conference, held from 17 July to 2 August 1945, the Council of Foreign Ministers was established from representatives of the USSR, USA, Great Britain, France and China. The following foreign ministers played a crucial role: James F. Byrnes, Vyacheslav M. Molotov and Anthony Eden, later Ernest Bevin and Georges Bidault.

The Council of Foreign Ministers was authorized to prepare the peace treaties with Italy, Romania, Bulgaria, Hungary and Finland. The Council was authorized to invite representatives of the state concerned by the discussed issue to the talks. The first session of the Council of Foreign Ministers after the Potsdam Conference took place in London from 11 September to 2 October 1945. ${ }^{1}$ The London Council of Foreign Ministers discussed general issues already, as well as the ethnographic boundary between Italy and Yugoslavia, but

1 United States Department of State. Foreign relation of the United States. Council of Foreign Ministers. Volume II. U.S. Government Printing Office (FRUS) http://digital.library.wisc.edu/FRUS.FRUS1946v02.i0007.pdf. 


\begin{tabular}{|c|c|c|c|}
\hline$\sqrt{*}$ & 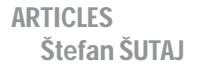 & 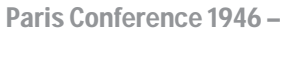 & 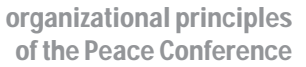 \\
\hline
\end{tabular}

an unambiguous consensus on the presented issues was not achieved. ${ }^{2}$ The reports of the Czechoslovak diplomats about the proposal of the Italian government submitted to the Council with respect to the issue of the Italian-Yugoslavian border ${ }^{3}$ pointed out in relation to the preparation of the mechanism of the negotiations about the peace treaties that after the protests of the Yugoslavian delegation against the equal approach of the Powers to the Yugoslavian and Italian delegation that there were considerable changes in the negotiation procedure. The Yugoslavian delegates could take part in the whole negotiations, while the Italian delegation could do so only if it had been invited for interrogations. The Yugoslavian delegation was present also at the interrogations of the Italian party and it could comment all its proposals. The argument was that Yugoslavia belonged to the United Nations while Italy was a defeated country. ${ }^{4}$

Another session of the Council of Foreign Ministers was held in Moscow on 16 - 26 December $1945 .{ }^{5}$ The ministers achieved an agreement about the preparation of the peace treaties, agreed the suggestions for adoption of the treaties with the allies of Germany and set the date of the Paris conference for May 1946. ${ }^{6}$

The agenda of the subsequent session and organizational issues were dealt with until the start of the subsequent session of the Council of Foreign Ministers. The mechanism of negotiations of the future peace conference was gradually shaped. The first proposal of the French delegation (Draft Regulation for the Paris Conference) was submitted to the secretariat of the Council of Foreign Ministers on 2 April 1946 and it was finally passed by the Council of Foreign Ministers in Paris on 7 July 1946. ${ }^{7}$ The draft set the basic principles of the conference organization, the official languages and the conference participants. Official access to the conference discussion was declared. The draft assumed different commissions (general, technical, economic, commission for territorial issues, military, for colonial issues...), including the option to create subcommissions as needed and the mechanism of their activities. As the correspondence before the Council negotiations in April 1946 shows, the following issues were considered important by the USA: the discussion about the French-Italian, Austrian-Italian, Italian-Yugoslavian borders, war crimes, human rights and elimination of fascism, the discussion about reparations, colonies and military issues. $^{8}$

\footnotetext{
2 Archiv Ministerstva zahraničních věcí (Archive of the Foreign Ministry, Praha, hereinafter referred only as AMZV), f. Generání sekretariát - odbor A (General Secretariat - Department A, hereinafter referred only as GS-A), card file 87, Ivan Krno's report from 11 October 1945. According to the publication of Dalibor M. Krno, the Council of Foreign Ministers did not discuss the issue of the peace treaties at its first session in autumn 1945 in London, nor did the deputies of the foreign ministers. KRNO, M. Dalibor: Paris 1946. Pripravoval sa mier s Mad'arskom, Praha 1947, 9-10.

3 AMZV, f. GS-A, card file 87, Report of the Czechoslovak delegation for peace negotiations from London from 2 October 1945.

4 Ibidem. FRUS, http://digital.library.wisc.edu/FRUS.FRUS1946v02.i0007.pdf, 38.

5 FRUS, http://digital.library.wisc.edu/FRUS.FRUS1946v02.i0007.pdf.

6 PETRUF, Pavol: Československo na mierovej konferencii v Parízi roku 1946, in: Historický časopis, 33, 1985, 1, 68.

7 FRUS, http://digital.library.wisc.edu/FRUS.FRUS1946v02.i0007.pdf, 38-42 [cit. 2015-01-15].

8 Telegram of the Assistant Secretary of State (Dunn) to the Secretary of State, April, 10, 1946 - April, 11, 1946, FRUS, http://digital.library.wisc.edu/FRUS.FRUS1946v02.i0007.pdf, 49 [cit. 2015-01-15].
} 
The basic coordinates of the foreign policy of the Allies did not change considerably, but they gradually acquired dimensions in which the peaceful assessment of the Central European situation played a more and more important role. In that period, the interested countries, i.e. the countries with which the peace treaties were to be made, as well as the countries of the winning coalitions, strived to make sure that their interests were included in the peace treaties. Aide memoires, memorandums, negotiations with the representatives of Big Four at different levels, meetings of ministers, secretaries of states and official delegations sent to the Big Four countries by the interested states were used to influence the preparation of the peace treaties. The states strived to assert their proposals at the negotiations of the Council of Foreign Ministers or to assure speeches of their representations at the sessions of the Council, respectively. The countries also submitted official requests in relation to the Council of Foreign Ministers, but the requests were addressed to the foreign ministers of the Great Powers. ${ }^{9}$

Another negotiation of the Council of Foreign Ministers was held in Paris in two parts, from 25 April to 16 May and then from 15 June to 16 July 1946. Additionally to the foreign ministers, the four participating countries sent support teams consisting of the most important politicians and experts on international relations, ambassadors and negotiators, experienced diplomats to the negotiations, which documented that they attached great importance to the meeting. ${ }^{10}$ Strategic issues of peace treaties had to be decided, but it also had to be decided whether and how the cooperation of the Victorious Powers would go on. ${ }^{11}$ A failure of the conference would have been perceived as failed effort for peaceful arrangement of the world.

The Council of Foreign Ministers that worked on the texts of the peace treaties in Paris from 15 June 1946, ended its activities on 12 July 1946. The basic articles of the treaties were agreed upon. Where no agreement was achieved, alternative proposals were submitted to be discussed only at the Peace Conference. ${ }^{12}$ The principles agreed upon at the negotiations were to be unchangeable and this principle was repeatedly referred to by the representatives of the Great Powers at the negotiations of the Paris Conference 1946. The agreed texts were to be modified only in exceptional cases. What was not settled in the course of the negotiations of the Council was, so to say, "lost".

On the penultimate day of the session of the Council of Foreign Ministers, on 11 July 1946, Dejean, the French ambassador passed two notes to the Czechoslovak foreign minister. One contained the official invitation for Czechoslovakia to the Peace Conference to be held from 29 July 1946, and the other contained organizational notifications related to the Peace Conference. The note included an exact description of the structure of the Conference as it was then really implemented. The note also informed that the peace treaty drafts

9 AMZV, f. GS-A, card file 148, Letter of V. Clementis to J. Slávik from 21 June 1946.

10 For the list of the delegation participants to the negotiations of the Council of Foreign Ministers held in Paris in 1946 see http://digital.library.wisc.edu/FRUS.FRUS1946v02.i0008.pdf, 88-94 [cit. 2015-01-15].

11 ČIERNA-LANTAYOVÁ, Dagmar: Tradícia a dejiny. Vybrané kapitoly zo slovensko-mad'arských a slovensko-ruských vztahov (1934-1949), Bratislava 2009, 89. Detailed records from the negotiations of the Council can be found in FRUS, http://digital.library.wisc.edu/FRUS.FRUS1946v02.i0008.pdf, 94-492 [cit. 2015-01-15]. Short reports sent to Washington from the session were published in 1947 and 1952 in memoir and documentation works of James F. Byrnes and Arthur H. Vandenberg who participated in the conference.

12 AMZV, f. GS-A, card file 88, Report of V. Clementis to J. Masaryk from 10 May 1946. 


\begin{tabular}{|c|c|c|c|}
\hline $\mathfrak{x}$ & 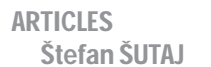 & 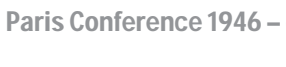 & 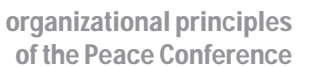 \\
\hline
\end{tabular}

would soon be delivered to the embassies in Paris. ${ }^{13}$ Hungary received the invitation to the Peace Conference, started on 29 July 1946, only on 5 August.

The peace treaties were prepared for the allies of Germany - for Italy, Hungary, Bulgaria, Romania and Finland. They were prepared as universal documents, generally utilizable for all former enemy countries. Their foundations were unified. In spite of a great effort of the deputies and foreign ministers, the unified text was not prepared as it had been expected. ${ }^{14}$ The peace treaty with Italy was the first to be prepared and it served as a model, ${ }^{15}$ complemented for treaties with the individual countries. The original drafts of the peace treaties contained both the provisions that had been unanimously agreed by the Great Powers and the provisions that had not been agreed and were formulated and submitted by individual proposers. Two variants of the peace treaty were made public in the course of the preparatory works. One variant contained only the texts that were specific to the given country, while the other articles referred to the articles of the peace treaties with other countries.

The full draft of the peace treaty with an ex-enemy country was made public also in full version, i.e. a draft with all proposed articles, not with references to the draft of the peace treaty with another country. For example the peace treaty with Hungary was made public in such a version on 16 July 1946. After the peace treaties had been officially submitted for the session, the countries involved had the opportunity to submit their comments to the peace treaties.

On 29 July 1946, the Paris Conference 1946 started. The Five Great Powers (USA, USSR, France, China, Great Britain) and the members of the United Nations, sixteen states whose military forces had actively participated in the war against the enemy states in Europe (Australia, Belgium, Belarus, Brazil, Canada, Ethiopia, Greece, India, Norway, New Zealand, Netherlands, Poland, Czechoslovakia, the South African Union, Ukraine, Yugoslavia) participated in its session. The representatives of the defeated states and of the invited allied states, not represented in the conference, were interviewed at plenary sessions and also at commissions, in some cases. The former enemy states were invited to the conference to submit their opinions.

The following bodies of the conference were created based on the decision of the Council of Foreign Ministers:

The Plenary Session dealt with the commission reports, adopted suggestions and could discuss any issue.

Commissions: The General Commission, including representatives of all countries involved (presided by Halvard M. Lange from Norway); the Military Commission, presided by Polish brigadier-general Mossor, and the Editorial Commission (presided by the Canadian Brooke Claxton). Two economic commissions: The Economic and Financial Commission on the Balkans and Finland - presided by Josef Korbel; the Economic and Financial Commission

13 AMZV, f. GS-A, card file 87, Record for the secretary of state about the invitation of Czechoslovakia to the Peace Conference from 12 July 1946.

14 The Assistent Secretary of State (Dunn) to the Secretary of State, Secret, Paris, July 19, 1946, FRUS, 1970 : http://digital.library.wisc.edu/1711.dl/FRUS.FRUS1946v03.i0010.pdf, 5-6 [cit. 2014-08-15].

15 SCHEU, Christian Harald: Pařǐžské mírové smlouvy v kontextu mezinárodního práva, in: Acta Universitatis Carolinae. luridica, 1, 2013, 302. 
on Italy - presided by the Indian Joseph Bhore. Five political and territorial commissions: The Political and Territorial Commission on Italy - presided by Lief Egeland, South African Union; the Political and Territorial Commission on Romania - presided by Dmitro Z. Manuilsky, Ukraine; the Political and Territorial Commission on Hungary - presided by Sinisha Stankovich from Yugoslavia; the Political and Territorial Commission on Bulgaria - presided by Kuzma V. Kiselev, Belarus; Political and Territorial Commission on Finland presided by John A. Beasley, Australia. The Commission for Procedural Issues - presided by the Belgian Paul-Henri Spaak - worked separately. Most countries involved strived to be represented in all of the above stated commissions, in order to have influence on and track of the negotiations of the commissions. The USSR and the USA had specialists in the commissions on each defeated country. The members of the commissions from the other, particularly smaller delegations overlapped. That was for example the case of the British, but also of the French representation.

From the perspective of the Czechoslovak Republic, the most important role was played by the Political and Territorial Commission IV - Hungary (Commissions politiques et territoriales IV - Hongrie) that discussed also the Czechoslovak demands, comments and amendments. The Czechoslovak politicians and media paid the greatest attention to its work. The commission was presided by Sinisha Stankovich from Yugoslavia; his deputy was Alfred T. Stirling from Australia. Alexey D. Voyna from Ukraine was a reporter of the commission. The commission chairmanship was elected at the first session by the commission members named by the individual states that had been in a state of war with the respective "enemy" country and by France as the conference organizer. The composition of the commission was subject to conflicts with the USSR delegation that had proposed that only the countries that had been in a state of war with the respective "enemy" country should have voting rights. The representation of delegates in individual commissions of the peace conference was confirmed by the Czechoslovak delegation based on a request of J. Fouques Duparc, secretary general of the Peace Conference, by a letter from 12 August 1946. ${ }^{16}$ The Political and Territorial Commission on Hungary (the Hungarian Commission) usually held sessions in the committee room No. 12 on the second floor of Palais du Luxembourg. The individual articles of the peace treaty with Hungary were assigned based on a decision of the secretariat of the commission. ${ }^{17}$

The individual commissions could create subcommissions for solution of special issues.

16 AMZV, f. Pařížská mírová konference (Paris Peace Conference, hereinafter referred only as PMK), card file 1. Letter from 12 August 1946 to J. Fouques Duparc, secretary general of the Peace Conference. The commission members were: USA - Walter Bidell Smith (USA ambassador to Moscow), James C. H. Bonbright, Frédéric Merrill; Australia - Evatt, Bevasley, Stirling, Hood; Belarus - Lioutorovitch; Canada - Brooke Claxton, M. A. Pope, L. D. Wilgress; France - Schneiter, Maurice Couve de Murville (head of the Political Department of the Foreign Ministry), Coulet, de Courcel; Great Britain - Hector Mc Neil, H. M. G. Jebb, W. G. Hayter a Viscount Hood; India - Navroji Wadia, R. S. Mani; New Zealand - W. J. Jordan, A. D. Mac Intosch, R. S. Park; Ukraine - M. Voyna; ZSSR - Fedor T. Gusev (ambassador to London), G. M. Pushkin (ambassador to Hungary), P. I. Veleshkain, I. S. Pereterskiy, F. N. Gryaznov; South African Union - Parminter, Jones, Jordan; Yugoslavia - Sinisha Stankovich. Burin des Roziers was the secretary of the commission, Richard Sears Jr. was the secrétaire associé and de Villneuve and sl. Merkling were the secrétair adjoints. Guide de la Conférence de Paris. Édition revisée le 22 août 1946. Paris: Palais du Luxembourg, 29 Julliet 1946, 51-52.

17 AMZV, f. PMK, card file 29, CP (sec) N. S. 103. Répartition des articles des traites de paix enter différentes commissions etablie par le secrétariat. 


\begin{tabular}{|c|c|c|c|}
\hline$x$ & 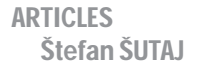 & 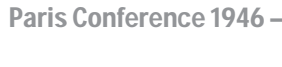 & 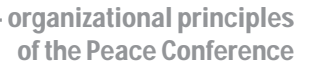 \\
\hline
\end{tabular}

The commission determined the contents of the subcommission activities by voting and it determined also its composition. The subcommission activities resulted in final reports (rapports). Two subcommissions were created in the Political and Territorial Commission on Hungary. The subject of the first commission consisted in dealing with the issues of the Vienna Arbitration Awards. Later, it was also charged with discussing the proposal for incorporation of five municipalities from Hungary to the Bratislava Bridgehead. The subcommission was established by the resolution of the Political and Territorial Commission on Hungary on 9 September 1946. The mechanism of the subcommission activities was determined by Point 3 of the Commission Resolution. "The Commission resolves unanimously to establish a subcommission charged with investigation of all documents (including those submitted to the Council of the Foreign Ministers) that, at the opinion of the Commission, are related to the issues resulting from the two proposed amendments submitted by the Czechoslovak government on paragraph 4 Art. 1 of the draft of the peace treaty with Hungary and from the report of the Commission on factual issues related to formulation of proposals it considered useful, with special regard to the principles formulated in the Atlantic Chart, as well as to the principles contained in Art. 55 of the United Nations. The Commissions makes unanimous decisions. 1 the Commission makes decisions independently, but it must go to examine the very place; 2 the subcommission will keep in contact with the Czechoslovak and Hungarian delegations; The following countries were unanimously elected members of the subcommission: Australia, Canada, New Zealand, Czechoslovakia and Ukraine." 18 The subject of the second subcommission consisted in the Czechoslovak demand on transfer of 200 thousand Hungarians from Czechoslovakia.

The activities of the subcommission frequently depended on the strategies and tactics of the individual delegations. In early September, at the sessions of the Hungarian Commission, particularly the USA believed that the transfer and the demand with respect to the Bratislava Bridgehead should be judged together. But the Czechoslovak Republic resisted such situation, to avoid the potential population exchange to be linked with the exchange theory; therefore it tried to achieve separate judgement of the said issues. ${ }^{19}$ Similar proposals were submitted also by the delegations of New Zealand and Australia. Stirling, the Australian delegate, proposed to create a subcommission that, "when investigating the border rectifications, could travel to the very place, and additionally, it could investigate all border issues and other issues existing between Czechoslovakia and Hungary and could act as a contact body between the commission and both delegations" ${ }^{20} \mathrm{~S}$. Stankovich, the commission president, stated that the rectification concerned Article 1, while the transfer issue concerned Article 4 and was not on the agenda. The Czechoslovak representatives tried to prevent an extension of its competences to negotiations on the territorial demands

18 AMZV, f. GS-A, card file 163, Resolution of the Hungarian Political Commission from 9 September 1946 on establishment of a subcommission.

19 AMZV, f. PMK, card file 20, Minutes of the meeting of the Political and Territorial Commission on Hungary, 9 September 1946; AMZV, f. PMK, card file 20, Political and Territorial Commission on Hungary. Record of Decision taken at the $9^{\text {th }}$ meeting held at the Luxembourg Palace, Paris on Monday, September, 9, $1946 \mathrm{CP}(\mathrm{H} / \mathrm{P})$, $9^{\text {th }}$ meeting, 10 September 1946. Annex A. Unites States Delegation. Statement in Connection with Czechoslovak Proposal Expand their "Bridgehead" in Hungary.

20 AMZV, f. PMK, card file 20, Minutes of the meeting of the Political and Territorial Commission on Hungary, 9 September 1946. 
of the Hungarian party. The Czechoslovak party considered junktiming of the demands on border rectification with the transfer a serious danger to its interests. It should be pointed out that the said model had been quite popular with the Hungarian public and politics from the beginning, and at the end, it found its place even in the Hungarian demands submitted to the Peace Conference. Vavro Hajdü, the head of the " $\mathrm{M}$ " department at the Foreign Ministry alerted at the meeting of the Czechoslovak delegates in Paris that if the subcommission is not charged with it, it could not junktime the issues but had to discuss them gradually. But at the same time, he stated that he had had to protest against attempts for other issues twice already in the subcommission, which showed that the tendency to link different issues in a common point and to try to join or interconnect them was not alien to the Peace Conference participants. ${ }^{21}$ The Czechoslovak demands were supported in the commission and in the subcommission particularly by the "Slavic" allies. On the contrary, in many cases, the British "territories" (Canada, New Zealand, Australia) supported the British and American proposals, particularly where the Western Great Powers did not see it fit to present the proposals, they submitted them with initiative.

English, Russian and French were the official languages of the Conference. ${ }^{22}$ The rules of procedure had been specified by a special commission for organization and procedure. At the plenary sessions, procedural matters were decided by a simple majority; the other matters were decided by two-third majority, but even decisions adopted by a simple majority were submitted to the Council of Foreign Ministers. The voting in the commissions was arranged in the following manner: the commission report was submitted as recommendation; if it was adopted by two-third majority, the minority could submit its statement and ask the plenary session for an opinion. If the commission did not achieve a two-third majority, it could submit multiple reports, and each commission member had the right to submit his statement and ask the plenum for an opinion, and alternative proposals were to be submitted to the plenum. Even if a two-third majority was achieved, the minority could submit its remarks. ${ }^{23}$ Only the states that had been in a state of war with the respective enemy state or that had fought in important war operation against it had the voting right. The negotiation principles of the United Nations applied at the Conference: a) each state had one vote; b) the speech duration could be limited; c) the negotiations were public on principle. Thus the Peace Conference renounced the principle of unanimity in international relations, by which, as Molotov said, the value of many recommendations was reduced. Unlike the Peace Conference after World War I, all participants of the Peace Conference had equal rights and were not subject to "offensive discriminations"; all negotiations were absolutely public; and the democratic rule of alternation in the presidency of the plenary sessions was adopted at the suggestion of the USSR, submitted at the San Francisco conference. ${ }^{24}$

21 AMZV, f. PMK, card file 1, Minutes of the meeting from 21 September 1946, held at the Czechoslovak embassy in Paris.

22 AMZV, f. Právní oddělení (Legal Department, hereinafter referred only as PO), card no. 118, Preparation of peace conferences after World War II.

23 AMZV, f. GS-A, card file 87, Record for the secretary of state about the invitation of Czechoslovakia to the Peace Conference from 12 July 1946.

24 AMZV, f. PO, card no. 118, Preparation of peace conferences after World War II. 


\begin{tabular}{|c|c|c|c|}
\hline$x \rightarrow 0$ & 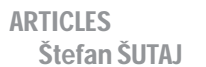 & 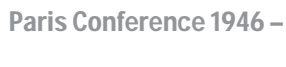 & 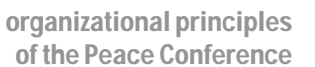 \\
\hline
\end{tabular}

The remarks on the treaties were distributed to the relevant commissions at the Peace Conference, reproduced in three languages and delivered also to all delegations. The following procedure was observed in the commissions: the remarks of former enemy countries were acknowledged, but they were introduced in the agenda only if at least one delegation of a state represented in the commission adopted them. ${ }^{25}$ In case of crucial issues, the commissions asked for opinions and oral explanation of the respective defeated country. The Hungarian delegation made use of the right to submit written remarks, as well as of the opportunity to address the commission presidents. It had the opportunity to present remarks also orally and in written at the Peace Conference plenum, but it could not discuss them. Due to the overlap of some issues, a joint session of the Political and Territorial Commissions on Hungary and Romania was held under participation of the Hungarian and Romanian representatives, as well as a joint session of the Hungarian and Czechoslovakian delegation. They were interrogated twice in the Political and Territorial Commission on Hungary - on the issue of the Bratislava Bridgehead and on the transfer of the Hungarians from Czechoslovakia. Additionally, they had the opportunity to submit written and oral remarks at the session of the subcommission in the matter of invalidation of the Vienna arbitration award. ${ }^{26}$

The invited (winning and co-operating) states could submit their corrections and proposals for changes of Peace Treaties to the Peace Conference secretariat. The proposals for changes of the Peace Treaty were submitted through amendments. ${ }^{27}$

The amendments to the Peace Treaties could be submitted only by the involved and invited states. The Big Four countries preparing the Peace Treaties usually did not submit any amendments. (The USSR submitted only one amendment to the treaty with Italy and Great Britain one to the treaty with Finland). List of amendments to all Peace Treaties: ${ }^{28}$

\footnotetext{
25 For example the Hungarian delegation proposed that the following sentence should be integrated in the preamble: "Hungary contributed efficiently to the termination of the war against Germany". As Hungary was not member of the commission, its remark could be discussed only if a member country of the commission adopted it. That did not happen and the president of the commission declared that the request of Hungary was rejected. (AMZV, f. PMK, card file 20, Minutes of the third meeting of the Political and Territorial Commission on Hungary, 24 August 1946.

26 KRNO, 29.

27 In English: amendment; in French: amendement, in Russian: popravka.

28 AMZV, f. PMK, card file 3, Répertoire des amendements.
} 


\begin{tabular}{|c|c|c|c|c|c|}
\hline Treaty with & \multirow[t]{2}{*}{ Italy } & \multirow[t]{2}{*}{ Romania } & \multirow[t]{2}{*}{ Hungary } & \multirow[t]{2}{*}{ Bulgaria } & \multirow[t]{2}{*}{ Finland } \\
\hline Proposing state & & & & & \\
\hline Australia & 17 & 13 & 13 & 13 & 13 \\
\hline Belgium & 1 & 1 & 1 & 1 & 1 \\
\hline Belarus & 2 & - & - & - & - \\
\hline Brazil & 9 & - & - & - & - \\
\hline Canada & 1 & - & - & - & - \\
\hline China & 2 & - & - & - & - \\
\hline Ethiopia & 5 & - & - & - & - \\
\hline Greece & 20 & - & - & 15 & - \\
\hline New Zealand & 1 & - & - & - & - \\
\hline Poland & 5 & 3 & 3 & - & - \\
\hline Great Britain & - & - & - & - & 1 \\
\hline Czechoslovakia & - & - & 15 & - & - \\
\hline $\begin{array}{l}\text { South African } \\
\text { Union }\end{array}$ & 1 & 1 & - & - & - \\
\hline Ukraine & 2 & - & - & - & - \\
\hline USSR & 1 & - & - & - & - \\
\hline Yugoslavia & 29 & - & 9 & - & - \\
\hline
\end{tabular}

No amendment was submitted by: France, India, Norway, Netherlands, USA. Australia submitted amendments to be applied to each treaty. They were assigned to all territorial commissions. The presidents and reporters of the commissions were in close contact in order to adopt identical decisions. ${ }^{29}$ Most Australian amendments were rejected.

Additionally to the proposals for change of the peace treaties in form of amendments, the individual delegations of the involved countries and the delegations of the defeated countries could submit their proposals (observations) resulting from the negotiations. That mechanism was used very frequently in the course of the activities of the individual commissions. The Hungarian government also submitted an amendment commenting the amendments submitted to the Peace Conference with respect to the Treaty with Hungary. ${ }^{30}$ But the amendment was not subject to the discussion of the Conference bodies. The activities of the commissions had a character of recommendation, similarly to the conclusions of the Paris Conference 1946 in general, and the final versions of the Peace Treaties were prepared by the Council of Foreign Ministers.

The Peace Conference was held in the Palais du Luxembourg. The plenary sessions took place in the semicircular room No. 165; the commissions met in other rooms. An informa-

29 AMZV, f. PMK, card file 29, C.P (sec) N. S. 110, Répartitition des amendements entre les différentes commissions.

30 AMZV, f. PMK, card file 2, Annexes. The Hungarian Delegation Reserves the Right to Submit Amendments at comments at a Later Date, 26 August 1946. 


\begin{tabular}{|c|c|c|c|}
\hline$x$ & 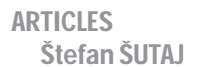 & 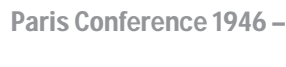 & 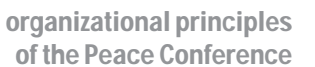 \\
\hline
\end{tabular}

tional booklet was issued at the occasion of the Peace Conference. ${ }^{31}$ It provided detailed information on the organizational issues of the Peace Conference, on the history of the Luxembourg Palace and on the composition of the delegations. The globe with the dove of peace and a ring saying "Conférence de Paris 1946" was the symbol of the Conference. The official name of the Conference was: Conférence de Paris 1946 - Paris Conference 1946. The official bulletin called Conférence de Paris was issued at the conference. A lot of trips, from thematic sightseeing tours through Paris to weekend or multiple-day trips all over France were prepared for the Conference participants, in different prices, from oneday trips for 1,750 to two-day trips for 3,750 to three-day trips for 6,500 francs. ${ }^{32}$

The work at the Peace Conference took place not only in the plenums and commissions but also during the time out of official negotiations. Therefore not only the creation of offices for the auxiliary staff of the individual delegations but also the places of their accommodation were of interest. They offered opportunities of immediate contacts, working and non-working meetings for example during the breakfasts served in the hotels. The Czechoslovak delegation stayed in the Plazza-Athénée Hotel in the Avenue Montaigne (Jan Masaryk, Vladimír Clementis, Fedor Hodža, Ivan Horváth, Josef Korbel, Juraj Slávik, Heliodor Píka, Dalibor Krno and others). Plazza-Athénée accommodated also the delegations of Ukraine, USSR, Belarus and Yugoslavia. That created conditions for "informal" meetings of the delegates and many times also for coordinated steps of the delegations (e.g. those of Yugoslavia and Czechoslovakia in connection with the effort to obtain objects of cultural heritage). ${ }^{33}$

The communist influence of the " $M$ " department of the Foreign Ministry could be seen also in the representation at the Peace Conference where the communist group around V. Clementis and V. Hajdů was complemented by G. Sekaninová-Čakrtová, D. Krno, L. Novomeský, V. Patzák and other clerks and journalists, which impacted the activities of the Czechoslovak delegation and was reflected in the co-operation with the diplomacies of the pro-Soviet Slavic bloc. Sloboda, the newspaper of the Slovaks in Hungary, issued in Budapest, published an essay on the position of Hungary at the Peace Conference in connection with Minister Zdeněk Nejedlýs travel to Yugoslavia. It stated that the Czechoslovak Republic was supported by the Soviet Union, Belarus, Ukraine and Yugoslavia. It did not ascribe it only to Slavic solidarity but particularly to the fact that the Soviet Union supported democratic states. ${ }^{34}$

The secretariat of the Czechoslovak delegation was in the Louvois Hôtel, in the Louvois Square where Karel Lisický, Vavro Hajdủ and the most officers and auxiliary staff stayed. ${ }^{35} 23$ journalists from Czechoslovakia were accredited to the Peace Conference. From the Slovak Press, only four journalists were accredited: Gabriel Terbots-Čechov (Čas), J. Šurina and S.

31 Guide de la Conférence de Paris. Édition revisée le 22 août 1946. Paris: Palais du Luxembourg, 29 Julliet 1946.

32 AMZV, f. PMK, card file 2, Excursion prevues.

33 For more details see: ŠUTAJ, Štefan: The Czechoslovak-Hungarian Disputes over The Cultural Heritage and Article 11 of the Peace Treaty with Hungary from 1947, in: Processes of Cultural Exchange in Central Europe in 1800-2000, VYMĚTALOVÁ, Karla - KNAPÍK, Jiří (eds.), Opava 2014, 255-283.

34 Mad'arsko na mierovej konferencii (jr), in: Sloboda, 1946, year II., no. 62, 18 September, 1.

35 AMZV, f. PMK, kart. 1, Zoznam ubytovaných osôb. 
Reis (Pravda), M. Šulc (Bojovník); the others came from the press agency and from different Czech newspapers (Zemědelské noviny, Brněnský čin, Mladá fronta, Svobodné slovo, Rudé práva, Právo lidu, Stráž severu and other newspapers). ${ }^{36}$ The Informations Tchécoslovaques bulletin was issued right in Paris. It brought information about the political and cultural life in Czechoslovakia, with particular focus on the contacts with the Allies. The base for the activities of the Czechoslovak delegation at the Peace Conference consisted of the representatives and employees of the Czechoslovak embassy to Paris, particularly Jindrich Nosek, the ambassador. Anonymous information for deputy Fedor Hodža, member of the peace delegation, alerted to serious problems in communication between the Foreign Ministry and Information Ministry even in Paris. The information pointed out competence disputes between the Information Ministry and the Foreign Ministry and the dominance of the pro-communist employees of the embassy in Paris who, nevertheless, did not succeed in penetrating into the French press circles and into the backstage of the Paris Conference. The Czechoslovak Information Office, established for the Peace Conference, consisted of 16 employees, and all of them were communists. Its activities cost 1,500,000 francs and, according to the informant, they resulted in ten articles published mostly in L'Humanité, a left-wing newspaper. The communist dominance could be seen also in the fact that if the French press or other interested persons addressed the office, communist representatives were usually recommended to them. From administrative perspective, the office was led by Löbl, a communist, and the political editorial office by Goldstücker and by Jiř́ Drtina, a young communist, nephew of minister Prokop Drtina, who was also reporter to the Czechoslovak Press Office, ČTK. All that was reflected in the press activities and management of promotional policy, under responsibility of the press department of the Information Ministry, led by Richard Slánský, brother of the secretary general of KSČ. ${ }^{37}$ The attitudes in the individual commissions, taken by the Czechoslovak delegates, were often subordinated to the creation of expected precedents in relation to the Peace Treaty with Hungary. The interconnection of Czechoslovakia with the Soviet Union could be seen also within the Peace Conference. It can be even stated that the development in the Peace Conference strengthened the bonds of Czechoslovakia to the Soviet Union..$^{38}$

The Hungarian delegation was accommodated in the Claridge Hotel, 74 avenue des Champs-Elysées. The list of the official delegates of former enemy countries to the Peace Conference was made public by the secretary general of the Peace Conference on 19 August 1946. The list included the following persons: János Gyöngyösi, head of the delegation; delegates: Pál Auer, László Farago and Pál Sebestyén, councellors (conseiller): Lórand Dabasi-Schweng, Aladár Szegedy-Maszák, Gyula Szekfü, István Vásárhely; secretary general: István Kertész; secretaries: Gédéon Dienes, László Homonnay, Zoltán Virágh; technical consultants: Robert Bérezy, Béla Demeter, László Gáldy, László Posfay, István Révay, Arthur Székely, Sándor Vajlok; secretariat: Elisabeth Frideczky, Hedvig Grabowsky, Irén

36 Archiv Národního muzea (Archive of the National Museum, Praha, hereinafter referred only as ANM), f. Fedor Hodža, card file 3, Liste des journalistes accredités auprès de la Conférence de Paris.

37 ANM, f. Fedor Hodža, card file 3, Žrízení československé tlačové kanceláře a o poměrech v ní.

38 AMZV, f. PMK, card file 1, Minutes of the meeting from 21 September 1946, held at the Czechoslovak embassy in Paris. 


\begin{tabular}{|c|c|c|c|}
\hline$\times$ & 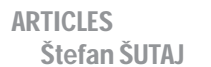 & 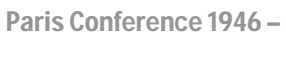 & 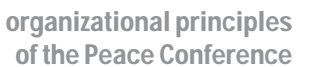 \\
\hline
\end{tabular}

Kiss, Anne-Marie Samarjay, Géza Szathmary. ${ }^{39}$

By 15 August 1946, 30 Hungarian journalists from the most important Hungarian magazines were accredited to the Peace Conference (e.g. Magyarország, Köztársaság, Világ, Magyar Nemzet...). ${ }^{40}$ The Hungarian delegation also experienced an internal conflict between the communist and civil (non-communist) policy. According to the Czech sources, the Hungarian communists did not dispose of such potential as the non-communist policy. The communists sent Minister Ernő Gerő to Paris, to help foreign minister J. Gyöngyösi. The former made use of his preceding acquaintances and of his knowledge of Russian for contacts with Molotov. The responsibility was divided among Gyöngyösi, smallholders, communists, but also socialists. Árpád Szakasits, their representative, arrived to Paris for the negotiations of the representatives of socialist parties. The envoy of Hungary to Paris and the member of the Hungarian delegation to the Conference, P. Auer, specially pointed out, when talking with T. Merill (secretary of the American delegation to the Conference), the situation in the Hungarian peace delegation and the fact that Elek Bolgár, the communist deputy of the foreign minister, did not meet the delegation in Paris due to an illness ("diplomatic illness"). Auer expressed the belief that the communist policy would not be involved in presenting the Hungarian policy in Paris. He also reminded that the draft of the Peace Treaty was considered national disaster by most Hungarians. ${ }^{41}$

The conference was usually chaired by a representative of the host country (France) and gradually by one other representative of a member state of the Council of Foreign Ministers (USA, USSR, Great Britain, China); the presidents and reporters of the respective commissions were elected by the commission members; the commission could not be chaired by a member of a state from the Council of Foreign Ministers, and one state could not chair more than one commission. Five presidents chaired the Paris Conference: James F. Byrnes, secretary of state, president of the delegation of the United States of America; Ouang Chih-Chieh, foreign minister, president of the delegation of China; Georges Bidault, minister president of the French Republic, president of the delegation of France; Ernest Bevin, secretary of state, president of the delegation of Great Britain; Vyacheslav M. Molotov, foreign minister, president of the delegation of the USSR.

The secretary general of the Peace Conference was: Jacques Fouques Duparc. The common secretariat of the Conference consisted of: Edward Page (USA); W. R. Hodgson (Australia); Jorge Latour (Brazil); Henry Ch. Chang (China); François Seydoux (France); W. D. Allen (Great Britain); V. J. Yerofeyev (USSR); Joza Vilfan (Yugoslavia) and additional members of the general secretariat: Claude Bouchinet-Serreulles and Jean-Paul Garnier. The cabinet of the general secretariat consisted of: Paul Bertrand - head of the secretariat, Philippe Clément - deputy of head of the secretariat; members: Jean de la Grandville, Gilles Curien and Henri de Beaumont and the head of the daily schedule service, Jean Dupuy.

Among the 21 delegations participating in the Conference, the delegation of Yugoslavia was the largest (120), followed by the delegation of the Soviet Union (91) that, together

\footnotetext{
39 ANM, f. Fedor Hodža, card file 3, Liste des délégation. E.g. The Italian delegation had 76 members.

40 ANM, f. Fedor Hodža, card file 3, Liste des journalistes accredités auprès de la Conférence de Paris.

41 Memorandum of Conversation Frederick T. Merrill-Auer of the United States Delegation, August, 2, 1946, pp. 81-84.

FRUS http://digital.library.wisc.edu/1711.dl/ FRUS.FRUS1946v03.i0015.pdf.
} 
with the formally independently acting delegations of Belarus and Ukraine had 115 members, and the delegation of the USA with 103 members. The members of the official delegations had the following representations: The Australian delegation had 34 members; Belgium - 24; Belarus - 13; Brazil - 38; Canada - 24; China - 47; Ethiopia - 13; France - 55; Great Britain - 48; Greece - 56; India - 23; Norway - 12; New Zealand - 10; Netherlands - 23; Poland - 28; Czechoslovakia - 49; South African Union - 18; Ukraine - 11. The needs of the delegations were satisfied by 61 interpreters into the conference languages and by the 33-member administration service of the conference. ${ }^{42}$

The sessions of the plenum and of the commissions or subcommissions were publicly accessible to the accredited delegation members and to journalists; only commission members could have speeches. Based on a special voting, any session could be declared secret, but such mechanism was used only sporadically. The representatives of the defeated states and of the invited allied states, not represented in the conference, could be interviewed at plenary sessions and also at commissions, in some cases. The former enemy states (exennemi) were invited to the Conference to submit their statements, but they did not have a status of equal Conference participants. They were not members of the commissions and were not allowed to intervene in the Conference negotiations. ${ }^{43}$

The daily program was defined several days before the meetings and the agenda included specific times and meeting rooms. The general secretariat issued also a list of codes to mark the documents issued by the Paris Conference. The final documents were marked with $\mathrm{CP}$; for example the documents of the plenary session had code CP (Plen); the documents of the Political and Territorial Commission on Hungary, $\mathrm{CP}(\mathrm{H} / \mathrm{P})$; the documents of the Economic Commission on the Balkans and Finland, CP (B et F/EC). ${ }^{44}$ Based on the codes, it is always possible to identify the respective material, its origin and affiliation to the organizational structure.

Each commission was responsible for the method of management of its work, for its working method, translations and interpretations of explanations, which was highlighted in the letter of the general secretariat of the Conference after reservations of some former enemy countries against the work of the individual commissions. ${ }^{45}$ The first negotiations of the Peace Conference took place in the plenum; later, in connection with submission of the amendments and with statements of the interested states on the Peace Treaties, set for 20 August 1946, and statements of the defeated countries, the activities of the individual commissions and of the subcommissions established by them started full operation.

The negotiations were lengthy and protracted, both in the plenum of the Conference and in the individual commissions, and there was danger that the negotiations of the Peace Conference would be extended. On 25 September 1946, French Foreign Minister Bidault sent a letter to Fouques Duparc, the General Secretary of the Conference, on behalf of the Council of Foreign Ministers that had met on 24 September 1946 and assessed the

42 Guide de la Conférence de Paris. Édition revisée le 22 août 1946. Paris, Palais du Luxembourg, 29 Julliet 1946.

43 AMZV, f. GS-A, kart. 165, Règles proposées par le Secrétariat pour l'audition... nations ex-ennemies.

44 AMZV, f. PMK, card file 29, Liste des Cotes des Documents.

45 AMZV, f. PMK, card file 29, C.P (sec) N. S. 118. Note du secrétariat interprétation et traduction, 6 September 1946. 


\begin{tabular}{|c|c|c|c|}
\hline$x x$ & 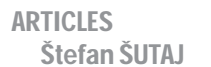 & 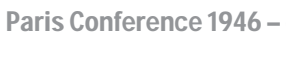 & 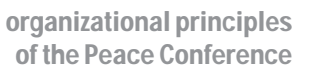 \\
\hline
\end{tabular}

current status of the work of the Conference. He asked the General Secretary, in connection with his letter from 11 September 1946, to ensure acceleration of the negotiations of the commissions of the Peace Conference. He also asked that the limits determined for the negotiations should be observed. The commissions were to prepare their reports by 5 October 1946, and to adapt their program so that they could ensure voting on all proposals and all amendments before the said date and deliver them to the plenary session. In connection with that, the plenary session should start discussing the reports on 5 October 1946 , so that the final documents would be adopted by 15 October 1946. ${ }^{46}$ Subsequently, decisions on acceleration of the work of the Peace Conference were adopted in the $27^{\text {th }}$ plenary session of the Peace Conference. ${ }^{47}$ Other measures to accelerate the activities of the Peace Conference were adopted too. One delegation could not get the floor with respect to one issue more than twice. The first speech was limited to 10 minutes; the second speech had only 5 minutes available. The president could proceed discretely with regard to this rule, if an important issue was discussed. As for procedural issues, each delegation had three minutes available, and the translations of the speeches should be available before the meeting already. ${ }^{48}$

On 5 October 1946, the principles of negotiation of the last plenary session of the Peace Conference were adopted. 1) The plenary session should study the Peace Treaties according to the rules agreed at the Berlin Conference: (one after another) Italy, Romania, Bulgaria, Hungary, Finland. 2) The reports of the commissions about each Peace Treaty draft were submitted in three languages at least two hours before the sessions. 3) The study (assessment) of each Treaty started by the general discussion. The delegations wishing to ask for the floor had to inform the general secretariat before the beginning of the meeting. The delegations had 30 minutes to speak on the draft of one treaty available. 4) The delegations were asked to submit the speeches in advance if possible, in order to provide for translation of its text. 5) After the end of the general discussion, the individual articles of the respective Peace Treaty were discussed. If unity was not reached, voting was performed by persons (namely). 6) The commission reports were presented in the following order: Political and Territorial Commission, Military Commission, Economic Commission. 7) No explanation of election and no new amendment could be accepted. The delegations could ask that findings explaining their attitudes were added to the minutes, and they could present explanations of their voting on all issues assessed by the Conference. 8) The time devoted to each Peace Treaty project was specified: three days for the Peace Treaty with Italy, one day for Peace Treaties with the Balkan states and Finland. 9) Each issue not addressed by the adopted rules should be addressed by the President of the Conference based on the Reglement of the Conference or of the United Nations. 10) The resolutions and recommendations adopted by the plenary session were to be established in compliance with the adopted rules of the Conference. ${ }^{49}$

46 AMZV, f. PMK, card file 29, C.P (sec) N. S. 126. Communication adressée au Secrétaire Générale de la Conférence par M. G. Bidault au nom Conseil des Ministres des Affaires Étrangères, 25 September 1946.

47 AMZV, f. PMK, card file 29, C.P (sec) N. S. 127. Résolutions adopté par la session plénière de la Conférence à sa 27e réunion du 26 septembre 1946, concernant l'accélération des travaux de la Conférence.

48 AMZV, f. PMK, card file 29, C.P (sec) N. S. 128. Ensemble des mesures destinées à accélérer les travaux des commissions, 27 September 1946.

49 AMZV, f. PMK, card file 29, C.P (sec) N. S. 135. Projet de règlement pour les dernieres séances de la con- 
The Paris Peace Conference ended on 15 October 1946. In the final votings, Czechoslovakia mostly voted in the Slavic bloc. There were differences with respect to the economic clauses where Czechoslovakia anticipated future votings in relation to the Peace Treaty with Hungary. In such cases, it voted pragmatically, as needed. The Conference approved a list of recommendations for the Peace Treaties. It adopted 94 recommendations that were later discussed by the Council of Foreign Ministers at final edition of the Treaties. Out of the 53 recommendations adopted by the Conference, 47 were adopted at least by two-third majority in verbatim wording or in almost verbatim wording for the final texts of the treaties. Out of the 41 recommendations adopted by lower majority, 24 were adopted for the final texts..$^{50}$ The final texts were to be delivered to the Council of Foreign Ministers together with the records on the choices and comments on the individual secret votes. The final Record of Recommendation by the Conference on the Draft Peace Treaty was the result. It summarized all proposals adopted by two-third majority with and without changes, as well as new articles. A special part contained articles adopted by a simple majority. ${ }^{51}$

The Council of Foreign Ministers elaborated the final texts of the Peace Treaties at the New York session from 4 November to 13 December 1946. The Peace Treaties were signed in Paris on 10 February 1947. The treaties were ratified by the parliaments of the Great Powers and of the countries signing the respective Peace Treaty. Example of the peace Treaty with Hungary. The Hungarian National Assembly adopted the Treaty unanimously on 27 June 1947. The American legislation approved the Peace Treaty with Hungary on 5 June the British in July and the Soviet on 31 August 1947. It was deposited in Moscow on 15 September 1947, and the Treaty came into force officially by that. ${ }^{52}$ In Czechoslovakia, the constituent National Assembly ratified the Peace Treaties of Czechoslovakia with Bulgaria, Romania, Finland, Italy and Hungary on 1 October 1946. They were published in the Statute Book. Act No. 172/1947 of the Statute Book adopted measures for implementation of the Peace Treaties with Hungary, Bulgaria, Italy, Finland and Romania.53

\section{Abstract}

The Paris Peace Conference 1946 in a significant manner interfered into the European and Central European politics. It became a place of confrontation but also a place of formation of basic lines of post-war political orientation and international political status of participating and involved countries. The preparations of peace agreements with Italy, Romania, Bulgaria, Hungary and Finland during the Potsdam Conference (July - August 1945) was delegated to the Council of Foreign Ministers, composed from representatives of Soviet Union, USA, Great Britain and China. The Council of Foreign Ministers submitted to the Paris Peace Conference held from 29 June 1946 till 15 October 1946 elaborated proposals of peace agreements.

férence plénière, 5 October 1946.

50 AMZV, f. PO, kart. 118. Preparation of peace conferences after World War II.

51 http://digital.library.wisc.edu/1711.dl/ FRUS.FRUS 1946v04.i0013pdf, 937-949 [cit. 2014-08-15]. Record of Recommendation by the Conference on the Draft Peace Treaty with Hungary.

52 ROMSICS, Ignác: Parĩzska mierová zmluva z roku 1947, Bratislava 2008, 323.

53 Vládní návrh Zákona o opatřeních k provedení mírových smluv s Bulharskem, Finskem, Itálií, Mad'arskem a Rumunskem, online: http://www.psp.cz/eknih/1946uns/tisky/T0827_00.htm. 


\begin{tabular}{|c|c|c|c|}
\hline$x$ & 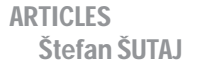 & 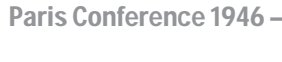 & 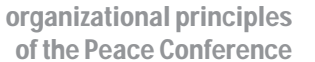 \\
\hline
\end{tabular}

The paper is dealing with mechanism of functioning of the Peace Conference (participants, invited states, relations toward hostile states). The paper is mapping overall activities of Peace Conference, activities of individual institutions (the Committee of Conference, commissions (political and territorial, economic and special commissions such as the Military Commission, the Commission for Processual Issues, the Comission for dealing with Press, the Editorial Commission, the Legal Commission and the General Commission), sub-commissions and processual issues of Peace Conference activities.

A special attention is given to the Political and Territorial Commission for Hungary, in frame of which were taken into consideration demands, additions and amendments brought-up by Czechoslovakia. In this context attention is given also Czechoslovak and Hungarian delegations and conditions in which both delegations were working. Primary attention is given to Czechoslovak demands submitted to the Peace Conference.

The Conference approved a list of recommendations to the peace agreements. Consequently the Council of Foreign Ministers elaborated definitive versions of peace agreements during the session in New York on December 1946. The signing of peace treaties was done on 10 February 1947 in Paris.

\section{Keywords}

Paris Conference 1946, Peace Treaties

\section{References}

Archiv Ministerstva zahraničních věcí (AMZV)

Archive of Foreign Ministry, Praha

f. Generální sekretariát - odbor A (GS-A), f. Právní oddělení (PO), f. Pařǐ̌ská mírová konference (PMK)

Archiv Národního muzea

Archive of the National Museum, Praha

f. Fedor Hodža

United States Department of State. Foreign relation of the United States. Council of Foreign Ministers. Volume II. U.S. Government Printing Office (FRUS), online: http://digital.library.wisc.edu/.

Vládní návrh Zákona o opatřeních k provedení mírových smluv s Bulharskem, Finskem, Itálií, Mad'arskem a Rumunskem, online: http://www.psp.cz/eknih/1946uns/tisky/T0827_00. htm.

ČIERNA-LANTAYOVÁ, Dagmar: Tradícia a dejiny. Vybrané kapitoly zo slovensko -mad'arských a slovensko-ruských vztáahov (1934-1949), Bratislava 2009.

Guide de la Conférence de Paris. Édition revisée le 22 août 1946. Paris, Palais du Luxembourg, 29 Julliet 1946. 
KRNO, M. Dalibor: Paris 1946. Pripravoval sa mier s Mad'arskom, Praha 1947.

Mad'arsko na mierovej konferencii (jr), in: Sloboda, 1946, year II, no. 62, 18 September, 1. PETRUF, Pavol: Československo na mierovej konferencii v Parízi roku 1946, in: Historický časopis, 33, 1985, 1, 67-82.

ROMSICS, Ignác: Parížska mierová zmluva z roku 1947, Bratislava 2008.

SCHEU, Christian Harald: Pař́žské mírové smlouvy v kontextu mezinárodního práva, in: Acta Universitatis Carolinae. luridica, 1, 2013, 299-310.

ŠUTAJ, Štefan: The Czechoslovak-Hungarian Disputes over The Cultural Heritage and Article 11 of the Peace Treaty with Hungary from 1947, in: Processes of Cultural Exchange in Central Europe in 1800-2000, VYMĚTALOVÁ, Karla - KNAPÍK, Jiř́ (eds.), Opava 2014, 255-283. 